Revista de

Contabilidade e

Organizações

www.rco.usp.br
DOI: http://dx.doi.org/10.11606/rco.v11i31.137775
Journal of

Accounting and

Organizations

www.rco.usp.br

\title{
Narcissism: are accounting students using their personality traits to perform better?
}

Narcisismo: estudantes de contabilidade estão usando seu narcisimo para melhorar o desempenho?

Gerlando Augusto Sampaio Franco de Lima; ${ }^{\mathrm{a}}$ Bruna Camargos Avelino ${ }^{\mathrm{b}}$; Jacqueline Veneroso Alves da Cunha ${ }^{\mathrm{b}}$

${ }^{a}$ University of Illinois at Urbana-Champaign

${ }^{b}$ Universidade Federal de Minas Gerais

\section{Keywords}

Narcissism.

Academic Performance.

Accounting Education.

Narcissistic Personality Inventory.
Palavras-chave

Narcisismo.

Desempenho acadêmico.

Educação em Contabilidade.

Inventário de Personalidade Narcisista.
Informações do Artigo

Recebido: 06 de setembro de 2017

Aceito: 22 de janeiro de 2018

\begin{abstract}
The purpose of this research was to identify if non-pathological narcissistic personality traits in accounting students are related to their performance. Students who overestimate their performance, a characteristic present in narcissistic individuals, live in the unrealistic belief that they do better than others in different activities. Such tendency can be detrimental in the long term. In addition to resulting in a constant effort so that such expectations become reality. The data were collected from a sample of 106 Brazilian accounting students who responded to a survey that included the Narcissistic Personality Inventory (NPI). The results suggest that the higher the presence of narcissistic traits, the greater his/her self-perceived academic performance. At same time, narcissism does not influence the student's real performance, which suggest that narcissistic personality traits just influence expectations, reather than the learning process.
\end{abstract}

\begin{abstract}
Resumo
O objetivo dessa pesquisa foi identificar se traços não patológicos de personalidade narcisista em estudantes de graduação de um curso de Ciências Contábeis estariam relacionados com o desempenho desses alunos. Estudantes que superestimam seu desempenho, uma característica de indivíduos narcisistas, vivem uma expectativa não realista que irão ter melhor desempenho que outros em diferentes atividades. Esse comportamento pode ser prejudicial no longo prazo, além de resultar em um constante esforço para que esta expectativa se torne realidade. Os dados foram coletados de uma amostra de 106 alunos de graduação em contabilidade que responderam um questionário contendo questões sobre traços de personalidade narcisista. Os resultados sugerem que quanto maior a presença desses traços narcisitas maiores as chances do desempenho atribuído pelo próprio estudante ser maior. Ao mesmo tempo, o nascisismo não influencia o desempenho real do aluno, o que sugere que esses traços de personalidade incluenciam apenas as expectativas, mas não o processo de aprendizado.
\end{abstract}

\section{Implicações práticas}

A personalidade narcisista pode superestimar o desempenho acadêmico percebido, e está presente em diferentes níveis na graduação em contabilidade. Conhecer esses traços daria aos estudantes a capacidade de gerenciar suas próprias expectativas de desempenho acadêmico. Futuramente os mesmos traços podem levar a falsas expectativas profissionais, e por vezes violar limites éticos.

Copyright (C) 2017 FEA-RP/USP. Todos os direitos reservados

\section{INTRODUCTION}

One of the differences between the current generation and previous ones is the current generation's level of narcissism (Dworkis, 2012). According to Trechera, Torre, and Morales (2008), historians, philosophers, sociologists, and social analysts generally agree that in recent decades society has reached an apogee of narcissism that is a central cultural theme (Mazlish, 1982; Valadez \& Clignet, 1987; Rojas, 2007), characterized by a strong concern, in all walks of life, about self-realization, to the detriment of the collective well-being (Severiano, 1999). 
According to Lasch (1983), in each era people develop their own peculiar forms of pathology, expressing in an exaggerated form the underlying social structure. In the era of Freud, hysteria and neuroses carried to extremes the personality traits associated with the earlier capitalist order - acquisitiveness, fanatical devotion to work, and intense repression of sexuality. Later, personality disorders started to attract growing attention, culminating in the appearance of patients whose problems did not fit into the traditionally defined diagnostic categories and who suffered not from specific symptoms, but rather from vague and poorly defined complaints of malaise. The growing preeminence of character disorders appears to mark an underlying change in the organization of personality, in what has been called inner-direction to narcissism (Lasch, 1983).

Although the study of narcissism has a long and celebrated tradition, starting in the late 1800s, and has attracted the attention of many leading theoreticians, including Freud and his more modern disciples (Kernberg, 1975; Kohut, 1977; Millon, 1981), narcissism did not emerge as a mental disease until the appearance of the book Diagnostic and Statistical Manual of Mental Disorders (DSM-III), published by the American Psychiatric Association (Miller \& Campbell, 2008). Narcissistic personality disorder (NPD) is currently defined as " [...] a grandiose sense of self-importance or uniqueness; preoccupation with fantasies of unlimited success; exhibitionistic need for constant attention and admiration; characteristic responses to threats to self-esteem; and characteristic disturbances in interpersonal relationships, such as feelings of entitlement, interpersonal exploitativeness, relationships that alternate between extremes of over-idealization and devaluation, and lack of empathy" (American Psychiatric Association, 2000). This concept has been extended beyond the confines of mental disease to include other tendencies, which can be differentiated into clinical and subclinical (non-pathological). While clinical narcissism is defined as a personality disorder, subclinical narcissism can be understood as a personality characteristic or trait, presented by many individuals who are considered "normal" (Wallace \& Baumeister, 2002; Brunell, Staats, Barden \& Hupp, 2011). In this article, when mentioning the concept of narcissism, except when specified otherwise, we mean narcissistic traits or non-pathological narcissism.

In interpersonal contexts, narcissistic traits serve as a mechanism for self-regulation, in which motivations, relationships with others, and self-regulation strategies interact, leading to narcissistic behavior (Campbell et al., 2011). Green (1988) offers the life narcissism connotation, referring to the positive function of narcissism, which integrates representations of the ego coherently, giving a sense of self-esteem and personal valorization. Other expressions are also used, such as constructive narcissism (Kets de Vries, 1994), productive narcissism (Maccoby, 2003), reparatory narcissism (Glad, 2002), and healthy narcissism (Brown, 1997).

Individuals with excessively narcissistic traits tend to show a strong sense of self-importance (Brown, Budzek \& Tamborski, 2009), or a strong sense of entitlement, characterized by a general feeling that they deserve more rewards and recognition than others (Campbell et al. 2004), see themselves more positively than their peers (Robins \& Beer, 2001), and believe they are better than others and strongly depend on positive feedback from others (Rhodewalt \& Morf, 1998). If this feedback is not obtained, such as in the case of failure, the narcissist responds with extreme expressions of negative emotions (Bushman \& Baumeister, 1998; Rhodewalt \& Morf, 1998).

These characteristics result in negative consequences for excessively narcissistic individuals, be it in professional, private, or academic life. With respect to the last aspect, Taylor (2005), for example, estimated that approximately $3 \%$ of university students could be diagnosed as probably suffering from narcissistic personality disorder. This was only considering clinical narcissism; so many others might present subclinical narcissistic tendencies (Weikel, Avara, Hanson \& Kater, 2010).

The problem that arises from this reality is that narcissistic traits among university students can be associated with difficulties such as aggressive reactions to criticism (Bushman \& Baumeister, 1998; Twenge \& Campbell, 2003). Besides this, narcissists in the academic setting tend to consider their performance to be exceptional when their real performance is often only middling (Wallace \& Baumeister, 2002). Also, they are more likely to want immediate rewards or pleasures instead of waiting and are less likely to seek to counsel (Hudson, 2012).

Therefore, greater attention needs to be paid to the phenomenon of narcissistic personality traits among university students. As stressed by Hudson (2012), future leaders preponderantly emerge from the ranks of college students, and narcissism is harmful not only to their performance by posing obstacles to learning but to society as a whole. In this context and in light of the aspects that have a particular bearing on accounting, the objective of this paper is to identify if the presence of non-pathological narcissistic personality traits among undergraduate accounting students is related to their performance. 
In the accounting field, studies on the theme mainly concentrate on the presence of narcissism among managers and the consequent influence on bookkeeping decisions and disclosure of management reports (Hales, Hobson \& Resutek, 2012; Dworkis, 2012), and other aspects have been little explored. This represents an incomplete treatment of the theme, since as Menon and Sharland (2011, p. 51) note, the characteristics inherent to narcissists, such as exaggerated positive opinions regarding their status, dominance, and intelligence, as well as a constant desire for power, "can cause problems in other aspects of an individual's life, including in their academic experience".

Recognition of narcissistic tendencies in undergraduate students enables a discussion of intervention strategies to help reduce the negative impacts caused by excessive non-pathological narcissism in the academic setting, and consequently, the future working environment into which the students will be inserted. Weikel et al. (2010) reinforce the idea that although individuals that express evident arrogance, in general, may do not show possible emotional or interpersonal suffering, they may need counseling after events that damage their often heightened self-esteem, such as repeated negative feedback from a professor. In recognizing narcissistic tendencies, members of the institution have the opportunity to identify maladaptive cognitions and seek alternative means to help the student to deal with uncomfortable situations while still in college, thus contributing to a better preparation for the working environment.

It should also be noted that, as Maccoby (2003) highlights, the "productive" and "unproductive" labels are not fixed over the lifetime of narcissists or even in the life of individuals in general. Someone that has been productive can, with significant effort and internal conflict, become unproductive, converting strength into a weakness. When unconscious or irrational needs become the driving force, the ability to take rational decisions and advance in the direction of a healthy aim is frustrated. This process can also occur in the opposite sense: someone that was irremediably stuck in unproductive and self-destructive behaviors can, with positive and active effort, become productive (Maccoby, 2003). Recognizing the importance of identifying heightened non-pathological narcissistic traits in students opens up the possibility of discussing measures that aim to stimulate a healthier form of narcissism.

\section{LITERATURE REVIEW}

The studies on narcissism address the theme from different perspectives: the construction of scales to measure the characteristic or the improvement of existing scales (Penney, Moretti \& Silva, 2008; Ackerman et al., 2011; Davis \& Brunell, 2012); the identification of patterns of narcissism (Westerman et al., 2012; Gungor, Eksi \& Aricak, 2012); and/or the correlation with learning Godkin \& Allcorn, 2009; Watson, 2012), disadaptive behaviors (Weikel et al., 2010; Golmaryami \& Barry, 2010; Lau et al., 2011; Pauletti et al., 2012), and academic dishonesty (Romanek, 2009; Brunell et al., 2011). In the Brazilian setting, the studies on the theme have been primarily published in the areas of education and psychology, for example, the studies by Severiano (1999), Caixeta (2011), and Langaro and Benetti (2014), among others. Severiano (1999) sought to understand the relationships between narcissism and advertising and showed for Brazilian and Spanish college students the ideas conveyed by advertising predominate in those students that present more heightened traits of narcissism.

Caixeta (2011), in turn, investigated psychological suffering in university students and the symptoms that affect the academic and social life of undergraduates at a private higher education institution in the Federal District. One aspect that stood out in the analysis is a significant portion of the students reported difficulty in expressing themselves in public, the narcissism is overshadowed by helplessness. Such experience is so intense that it makes any manifestation of narcissism as the love of oneself impossible, the students remain at the mercy of the approval and acceptance of others. The students' experiences of suffering manifest themselves, according to Caixeta (2011), as anguish, anxiety attacks, headaches, stomach pains, insomnia, shaking, agitation, worry, isolation, irritability, sweating, and compulsive eating or abstinence from it. These symptoms affect not only the body, but also the subject's interpersonal relationships, work, and studies.

Finally, Langaro and Benetti (2014) analyzed characteristics of narcissism, depression, anxiety, desperation, and self-esteem in 350 young college adults. As a result, they obtained a positive correlation between narcissism and self-esteem, between anxiety and depression, and between depression and desperation. Specifically, in relation to narcissism, the authors highlight that many of the costs associated with this personality trait are faced by other people and not by the narcissists themselves. These costs include relationships with romantic problems, aggression, attacks, "white collar" crimes, etc. Therefore, the implications of an increase in narcissism can be positive; however, if exacerbated, they can become negative characteristics for other people, for society, and for the individual. 
In accounting academic context, the following studies can be mentioned: D'Souza (2016), Lopes, Cardoso, Reina, and Reina (2016), Avelino and Lima (2017), and Avelino, Lima, Cunha, and Colauto (2017). While D'Souza (2016) carry out an analysis of the named Dark Triad's personality characteristics (narcissism, psychopathy, and Machiavellianism), the pre-test carried out on 30 accounting undergraduate students at a public university presented $70 \%$ of them with low Dark Triad personality traits. Lopes et al. (2016) also investigated the Dark Triad construct on, using accounting graduate students at a Federal University, and verified some of them with a moderate level of Machiavellianism (68.83\% of the students), or a moderate level of narcissism (66.4\%), but a low level of psychopathy (45.85\% of them). Avelino and Lima (2017) and Avelino, Lima, Cunha, and Colauto (2017), in turn, investigated a possible (but not confirmed) relationship between narcissism and dishonesty. Their initiatives were the first concerning dishonesty in the academic environment and the second related to dishonesty in the professional context.

In this study, we intend to identify if non-pathological narcissistic personality traits in accounting students are related to their performance, which is a relationship that has not yet been verified in the national studies consulted. According to Wallace and Baumeister (2002), high levels of self-confidence and self-efficacy have been associated with higher achievement, so there are good theoretical reasons to support the premise that narcissism can make success more likely. However, with respect to empirical evidence, the authors observe that the results have been contradictory in examining possible links between narcissism and performance. Gabriel, Critelli, and Ee (1994, p. 151), in a survey of 146 undergraduate students, found that " [...] as compared to relatively objective assessments, those high in narcissism possess an inflated and sometimes grandiose view of their intelligence and attractiveness". For males and females, "[...] narcissism was correlated with intelligence self-illusion” (Gabriel et al., 1994, p. 147), what was not observed in relation to the actual intelligence. Likewise, John and Robins (1994) found results indicating that while the individuals classified as narcissistic in their survey believed themselves to be good at carrying out a task, the assessments of observers indicated the absence of differences in this respect between narcissistic participants and others in the study. Equivalent results were found by John and Robins (1994) and Farwell and Wohlwend-Lloyd (1998).

Previous studies have thus demonstrated that narcissists tend to overestimate their performance (Wallace \& Baumeister, 2002). In the academic setting, and even when starting on a career path, this overestimation of performance can be classified as adaptive in the short run, since narcissistic individuals have positive opinions of themselves. With time, however, this self-esteem erodes, leading to negative long-term results for those with this type of personality. These negative results, in turn, or even the possibility of facing them, can stimulate narcissistic individuals to violate ethical rules in search of better performance. Consequently, the inflated expectation of performance can, in the long run, hamper the adaptation of narcissists to the environment where they work, since although it is obviously beneficial to be optimistic about personal skills, at some point a realistic evaluation must be considered to attain real success (Hudson, 2012).

To investigate the relationship between narcissism and performance, we formulated the following hypotheses:

$\mathbf{H}_{1}$ : The higher narcissistic traits influence students to assume their (self-perceived) academic performance to be superior than the average.

$\mathbf{H}_{2}$ : The high narcissistic traits do not necessarily tend to be converted in real academic performance.

\section{METHODOLOGY}

The sample in this study is non-probabilistic, covering accounting undergraduate students at the University of São Paulo (USP), including those entering the classes of 2014, 2015, and 2016. One of the business schools of University of Sao Paulo, in Sao Paulo city, was selected as one of the authors obtained permission to access the students and their academic performance for that semester. The University of São Paulo is a high standing among Brazilian Higher Education Institutions. As a public university maintained by the São Paulo state government, its national preeminence is observed in Brazilian and international rankings.

We decided not to apply the questionnaire to students entering in 2013 because in the first semester of 2016 (when the data were collected) they were mainly taking distance-education classes in elective subjects, in dispersed groups. The questionnaire had been previously applied to 20 students in a pre-test within accounting and finance undergraduate courses at the Federal University of Minas Gerais. Those students were not included in the final sample. 
The research instrument was adequate to the Brazilian context, considering corrections of grammatical errors and/or typing, as also observed in the study by Avelino, Lima, Cunha, and Colauto (2017).

We gather the data through a printed questionnaire, applied between April 11 and 13, 2016. We considered students taking night classes enrolled in compulsory disciplines at that time. All told, 106 students answered the questionnaire.

The final questionnaire, after adjustments resulting from the pre-test, was composed of three parts: i) general data on the respondent, including gender, age, marital status, and engagement in paid work, among others; ii) the Narcissistic Personality Inventory (NPI), to identify the presence of narcissistic personality traits; and iii) self-evaluation of performance during the academic career.

Empirical research about non-pathological narcissism mainly developed after the creation of the Narcissistic Personality Inventory (NPI), a self-reporting questionnaire formulated by Raskin and Hall (1979) with the objective of measuring levels of subclinical narcissism (Wallace \& Baumeister, 2002). The NPI was not designed to identify a disease, it has become a standard for measuring narcissism in populations considered to be "normal". The NPI score is a forced-choice measure, where each item contains a pair of statements (for example: "When people compliment me I sometimes get embarrassed" against "I know that I am good because everybody keeps telling me so"). One point is attributed to each answer considered to reflect narcissism, and zero for the other alternative (Brunell et al., 2011). The level of narcissism is hence obtained by the sum of the points on all the items, with higher values indicating stronger narcissism. In this study, we used the version with 40 items.

The students' academic performance was initially obtained from their own assessments (self-perceived academic performance), by asking them to classify themselves as superior (above average - highest 50\%) or inferior (below average - lowest 50\%), according to the model from Cornachione Junior, Cunha, De Luca, and Ott (2010). The real performance was obtained from the university's student affairs office, with the students' agreement. The real performance was proxied by their grade point average (from 0 to 10) during the preceding semester.

Our expectation was thus that the higher the score in the Narcissistic Personality Inventory (NPI), the greater the probability would be of the student classifying his/her academic performance as superior, in light of the findings of Gabriel et al., (1994), John and Robins (1994), Farwell and Wohlwend-Lloyd (1998), Wallace and Baumeister (2002), and Hudson (2012), that narcissistic individuals tend to overestimate their performance. With respect to real performance, although good theoretical reasons exist to sustain that narcissism can increase the chances of success (Wallace \& Baumeister, 2002), based on empirical findings we did not expect the real academic performance of students with stronger narcissistic personality traits to be better than the average, in line with the findings of Gabriel et al., (1994), Farwell and Wohlwend-Lloyd (1998), and Wallace and Baumeister (2002).

To test the association between narcissistic personality traits and school performance among Brazilian undergraduate students majoring in accounting, we estimated two models. In the first model, the dependent variable refers to self-perceived academic performance. This variable is dichotomic, representing the self-evaluation of the students as being superior or inferior to the average. The explanatory variable "narcissism" represents the total score obtained in the Narcissistic Personality Inventory (Raskin \& Hall, 1979; Raskin \& Terry, 1988).

We also included control variables gender and classification in the university entrance exam, maintaining the same line of thought regarding the investigation of real performance. Therefore, although this model considers the students' self-reported performance rather than real performance per se, the prevalent reasoning is those female students would present a higher expectation of superior performance. This finds empirical support in the study by Cornachione Junior et al., (2010), who in analyzing 826 undergraduate students at four universities located in different Brazilian states, found that a higher percentage of female students classified themselves as having superior academic performance (70\%) compared to their male peers $(59 \%)$.

Analogously, we assumed that students with higher entrance exam classifications would consider their academic performance to be superior, following the reasoning that previous good performance makes students more self-confident in their abilities.

In the second model, the dependent variable refers to the student's real performance during the previous semester, measured by the grade point average (from 0 to 10). The explanatory variable "narcissism", as in the previous model, represents the total score obtained in the Narcissistic Personality Inventory (Raskin \& Hall, 1979; Raskin \& Terry, 1988). We also included some control variables that can be related to academic performance, such as gender, socioeconomic variables, and classification in the college entrance exam (Table 1). 
Table 1. Control variables included in Model II

Variables Description

A qualitative dichotomic variable, with a value of 1 for females and 0 for males. Previous studies Gender of differences in academic performance have demonstrated that in the samples analyzed, female students perform better (higher grades) than their male classmates (Duckworth \& Seligman, 2006; Magalhães \& Andrade, 2006; Araújo, Camargos, Camargos \& Dias, 2014).

Qualitative variables that indicate the level of schooling of the parents (through eighth grade, high school graduate, college graduate) and main type of school before entering university (public or private). Queiroz (2003) performed a study of inequality in higher education, analyzing the relationships between race, status, and performance of students at the Federal University of Bahia, Brazil. The author found that students coming from private high schools, regardless of race, had

Socioeconomic better school performance. Likewise, Menezes Filho (2006) examined the performance of Brazilian variables students in the fourth through eighth grades and concluded that factors linked to characteristics of the students and their families best explained their school performance, among these the mother's education level. Finally, Guimarães and Arraes (2008) analyzed the impact of some socioeconomic variables on the performance of candidates who took the entrance exam for the Federal University of Ceará, Brazil. Of the socioeconomic variables considered, the fact of working and having graduated from a public high school had a negative effect on the success in the entrance exam. On the other hand, the level of schooling of the parents had a positive effect on the entrance exam results.

Classification A variable that denotes the student's position in the entrance exam (the better performance in the exam obtained on the the higher variable value). Various studies have shown that previous performance has an influence university entrance on future performance (Kalbers \& Weinstein, 1999; Byrne \& Flood, 2008; Aldin, Nayebzadeh \& exam Heirany, 2011; Ferreira, Santos, Miranda \& Leal, 2014).

Source: Personal collection.

\section{ANALYSIS OF THE RESULTS}

The data regarding the analyzed sample (Table 2) reveal that $90.57 \%$ of the students are single, $36.79 \%$ have an average age of up to $20,67.93 \%$ are male, $53.77 \%$ joined the course, predominantly, in $2015,47.17 \%$ are predicted to graduate in $2018,58.49 \%$ underwent high school at private institutions, and $67.92 \%$ are engaged in full-time jobs. 
Table 2. Students'demographic and background information $(n=106)$

\begin{tabular}{|c|c|c|c|}
\hline & & Frequency & $\%$ \\
\hline \multirow{2}{*}{ Marital status } & Single & 96 & 90.57 \\
\hline & Married & 10 & 9.43 \\
\hline \multirow{3}{*}{ Age } & Up to 20 years old & 39 & 36.79 \\
\hline & Between 21 and 30 years old & 55 & 51.89 \\
\hline & Over 30 years old & 12 & 11.32 \\
\hline \multirow{2}{*}{ Gender } & Female & 34 & 32.07 \\
\hline & Male & 72 & 67.93 \\
\hline \multirow{6}{*}{ Year the course started } & 2010 & 3 & 2.83 \\
\hline & 2011 & 3 & 2.83 \\
\hline & 2012 & 10 & 9.43 \\
\hline & 2013 & 9 & 8.49 \\
\hline & 2014 & 24 & 22.64 \\
\hline & 2015 & 57 & 53.77 \\
\hline \multirow{5}{*}{ Expected year of graduation } & 2016 & 16 & 15.09 \\
\hline & 2017 & 29 & 27.36 \\
\hline & 2018 & 50 & 47.17 \\
\hline & 2019 & 9 & 8.49 \\
\hline & Not reported & 2 & 1.89 \\
\hline \multirow{3}{*}{ Where he/she spent most high school years } & Public high schools & 43 & 40.57 \\
\hline & Private high schools & 62 & 58.49 \\
\hline & Not reported & 1 & 0.94 \\
\hline \multirow{2}{*}{ Relevant extracurricular activity, paid or not } & Yes & 32 & 30.19 \\
\hline & No & 74 & 69.81 \\
\hline \multirow{2}{*}{ Full time-jobs } & Yes & 72 & 67.92 \\
\hline & No & 34 & 32.08 \\
\hline \multirow{4}{*}{ Father's schooling } & Middle school & 23 & 21,70 \\
\hline & High School & 29 & 27,36 \\
\hline & College & 52 & 49,06 \\
\hline & Not reported & 2 & 1,88 \\
\hline \multirow{4}{*}{ Mother's schooling } & Middle school & 18 & 16,98 \\
\hline & High School & 35 & 33,02 \\
\hline & College & 50 & 47,17 \\
\hline & Not reported & 3 & 2,83 \\
\hline
\end{tabular}

\section{Source: Personal collection.}

Regarding the fact that the majority of the students analyzed are engaged in some type of paid employment, this scenario may be attributed to the shift in evening accounting courses, given that studying in the evening facilitates combine full-time jobs and evening classes. Although most of the students in the sample predominantly went to high school from private institutions, a rising tendency of students originating from state schools is observed at the University of São Paulo.

\subsection{Relationship between Narcissism and Academic Performance}

Before estimating the regression models, we present the descriptive statistics of the Narcissistic Personality Inventory, as well as the academic performance (self-perceived and real performance) of these students (Table 3). The real academic performance is the weighted average of the all courses concluded by the student during the semester, varying from 0 to 10 . But, most of the respondents $(72.64 \%)$ consider their (self-perveived) performance compared to their peers to be superior (above average). 
The maximum score possible in the Narcissistic Personality Inventory is 40 points, 27 points being the maximum value obtained in this study. The average score of the Narcissistic Inventory $(=12.62)$ for the sample was lower than the average scores reported in a wide range of international studies (Raskin \& Terry, 1988; Foster, Campbell \& Twenge, 2003; Young \& Pinsky, 2006; Miller \& Campbell, 2008; Trzesniewski, Donnellan \& Robins, 2008; Miller et al., 2009), although these studies were not necessarily carried out on accounting undergraduate students.

Table 3. Descriptive statistics: Narcissistic Personality Inventory and Academic Performance

\begin{tabular}{lccccc}
\hline Variables & Obs. & $\begin{array}{c}\text { Mean/ } \\
\text { Median }\end{array}$ & $\begin{array}{c}\text { Standard } \\
\text { Deviation }\end{array}$ & Min. & Max. \\
\hline Narcissistic Personality Inventory & 106 & 12.6226 & 6.169746 & 2 & 27 \\
Real performance (0 to 10) & 106 & 7.2528 & 0.868080 & 5.5 & 9.4 \\
Self-perceived performance (above average =1) & 106 & 1 & 0.4479 & 0 & 1 \\
\hline
\end{tabular}

Source: Personal collection.

The Narcissistic Personality Inventory can be split into its seven subscales (Table 4), as Raskin and Terry (1988) states. The subscales are authority, self-sufficiency, superiority, exhibitionism, exploitativeness, vanity, and entitlement. This procedure was also carried out in the study by Avelino, Lima, Cunha, and Colauto (2017). The following characteristics were already mentioned as attributes of narcissistic individuals: exhibitionism, with feelings and thoughts of omnipotence that involve controlling/exploiting others, vanity, intolerance to criticism, a tendency to be critical of others that are different from oneself, as well as considering oneself to be self-sufficient and not needing anyone, among others. The "entitlement" item relates to a sense of right and expectations of special privileges over others and special exemptions from normal social requirements (Raskin \& Terry, 1988).

Table 4. Descriptive statistics: sub-categories of the Narcissistic Personality Inventory

\begin{tabular}{|c|c|c|c|c|c|}
\hline Variables & $\mathbf{n}$ & Mean & Standard Deviation & Min. & Max. \\
\hline Authority & 106 & 3.40566 & 2.22016 & 0 & 8 \\
\hline Self-Sufficiency & 106 & 1.44339 & 1.09614 & 0 & 4 \\
\hline Superiority & 106 & 1.29245 & 1.24951 & 0 & 5 \\
\hline Exhibitionism & 106 & 2.20754 & 1.44563 & 0 & 6 \\
\hline Vanity & 106 & 0.98113 & 1.03262 & 0 & 3 \\
\hline Entitlement & 106 & 1.78301 & 1.39389 & 0 & 5 \\
\hline
\end{tabular}

Source: Personal collection.

Note: Scales (min-max): Authority: 0-8; Self-Sufficiency: 0-6; Superiority: 0-5; Exhibitionism: 0-7; Exploitativeness: 0-5; Vanity: 0-3; Entitlement: 0-6.

The main item that stood out was Authority (=3.41), the narcissist's ability to influence other individuals with his/her belief that he/she is a successful, confident person who is a good leader and feels good demonstrating authority is mentioned. The mean is visibly higher than those presented in the remaining subscales, similar to Avelino, Lima, Cunha, and Colauto (2017)'s sample. The Exhibitionism, the second highest mean (=2.21), means narcissists' pleasure in being the center of attention and creating new trends, styles, and customs, among others. Vanity, the lowest mean $(=0.98)$, infers the individuals' propensity to focus the body, whether covering pleasure in exhibiting it or in looking at oneself in the mirror.

\subsubsection{Model I: Relationship between Narcissism and Self-Perceived Academic Performance}

Table 5 presents the results of the logistic regression model by the stepwise approach. The model can be evaluated as globally valid following analysis of the likelihood ratio statistic (LR statistic), since the p-value is lower than the established $\alpha$ value $(0.05)$. 
Table 5. Results of the binary regression model of the probability of the respondents assessing their self-perceived academic performance as superior - stepwise approach.

\begin{tabular}{lcccc}
\hline Variables & Coefficients & $\begin{array}{c}\text { Standard } \\
\text { Error }\end{array}$ & $\mathbf{Z}$ & p-value \\
\hline Constant & 4.545543 & 1.10967 & 4.10 & 0.000 \\
Narcissism & 0.128485 & 0.05219 & 2.46 & 0.014 \\
Classification in the entrance exam & 0.093922 & 0.01938 & -4.84 & 0.000 \\
Gender (female=1) & -1.495639 & 0.65349 & -2.29 & 0.022 \\
\hline
\end{tabular}

Source: Personal collection.

Note: 106 observations, with pseudo- $\mathrm{R}^{2}=0.3853$, Prob $>\mathrm{chi}^{2}=0.000$.

Both narcissism, gender, and classification in the entrance exam influence are statistically significant ( $\mathrm{p}$-value $<\alpha$ ) and positive on the probability of the students evaluating their own academic performance as superior. However, the estimated coefficients show a good deal of variation in the logarithm of the likelihood ratio, given the unitary increase in the variables considered. To obtain the direct influence of each explanatory variable on the probability of the students evaluating their academic performance as superior, we calculated the marginal effects, presented in Table 6.

Table 6. Calculation of the marginal effects

\begin{tabular}{lcccc}
\hline Variables & $\begin{array}{c}\text { Marginal } \\
\text { Effect }\end{array}$ & $\begin{array}{c}\text { Standard } \\
\text { Error }\end{array}$ & $\mathbf{Z}$-value & 0.015 \\
\hline Narcissism & 0.0152158 & 0.00628 & 2.42 & -4.78 \\
Classification on the entrance exam & 0.0111226 & 0.00233 & 0.000 & -2.00 \\
Gender (female=1) & -0.2156301 & 0.10784 & 0.046 \\
\hline
\end{tabular}

Source: Personal collection.

The analysis of the marginal effects indicates that unitary increases in the narcissism variable, represented by the total score obtained in the Narcissistic Personality Inventory, caused an increase of 0.01 percentage point in the probability of self-assessment of superior academic performance. This result supports the first hypothesis in this study, that means narcissistics students are more likely to consider their academic performance (self-evaluation) to be superior. The results are similar to previous studies from Gabriel et al., (1994), John and Robins (1994), Farwell and Wohlwend-Lloyd (1998), Wallace and Baumeister (2002), and Hudson (2012), where narcissistic individuals tend to overestimate their performance.

About the classification obtained in the entrance exam, we also confirm the expected effect. Individuals better ranked in the selection process were more likely to consider their academic performance to be superior. Previous studies (Kalbers \& Weinstein, 1999; Byrne \& Flood, 2008; Aldin et al., 2011; Ferreira et al., 2014; Baccaro, 2014) have found that the prior performance of students exerts an influence on their future performance. Our results indicate the same pattern. The students' previous good performance made them more self-confident and optimistic about their abilities, although no conclusions can be drawn from this model about the real performance of these students. Notwithstanding, the expected gender effect was not observed, which is dissimilar to previous empirical results by Cornachione Junior et al., (2010).

To consider the model correct and incorrect classifications, based on a cutoff point of 0.5 , were presented $82.08 \%$ of correct classification of self-perceived performance. Of the 77 students referring to their performance as superior, the model captures 70 as a good true positive rate $(90.91 \%)$ for students who evaluated their academic performance as superior. On the other hand, for the students who evaluated their academic performance as inferior, the classification was correct only $58.62 \%$ of the time. The low specificity reveals a limitation in the predictive power of the regression. Nevertheless, the model generally presented a good fit in terms of the predictionexpectation table.

\subsubsection{Model II: Relationship between Narcissism and Real Academic Performance}

The Model II investigates whether narcissism and the students' real performance are associated. The dependent variable is the average grade for the previous semester ( 0 to 10$)$, as a function of narcissism, proxied by the total score of the Narcissistic Personality Inventory. 
We included control variables as gender, mother's and father's schooling, type of high school (public or private), and classification in the entrance exam. The correlation matrix guarantees the absence of a strong correlation. The potential heteroskedasticity was mitigated by the Breusch-Pagan test. The p-value $(0.0453<$ 0.05 ) implies that the model residuals do not have constant variance. Therefore, we re-estimated the regressions considering robust standard errors. Table 7 presents the regression coefficients, the first column with all the explanatory variables and the second with a stepwise approach, both estimated with robust standard errors.

Table 7. Regression model - relationship between narcissism and real performance

(1)

(2)

\begin{tabular}{|c|c|c|}
\hline Variables & Real performance & Real performance \\
\hline \multirow{2}{*}{ Narcissism } & -0.00349 & \\
\hline & $(0.00636)$ & \\
\hline \multirow{2}{*}{ Classification in the entrance exam } & $0.0343 * * *$ & $0.0339 * * *$ \\
\hline & $(0.00222)$ & $(0.00220)$ \\
\hline \multirow{2}{*}{ Student from public hight school } & $0.209 * *$ & $0.276 * * *$ \\
\hline & $(0.0985)$ & $(0.0835)$ \\
\hline \multirow{2}{*}{ Gender $($ female $=1)$} & -0.0580 & \\
\hline & $(0.0797)$ & \\
\hline \multirow{2}{*}{ Mother's schooling - High School } & -0.211 & \\
\hline & $(0.155)$ & \\
\hline \multirow{2}{*}{ Mother's schooling - College } & -0.213 & \\
\hline & $(0.162)$ & \\
\hline \multirow{2}{*}{ Father's schooling - High School } & -0.0170 & \\
\hline & $(0.136)$ & \\
\hline \multirow{2}{*}{ Father's schooling - College } & -0.0429 & \\
\hline & $(0.142)$ & \\
\hline \multirow{2}{*}{ Constant } & $8.820 * * *$ & $8.515 * * *$ \\
\hline & $(0.197)$ & $(0.0872)$ \\
\hline Observations & 106 & 106 \\
\hline Adjusted $\mathrm{R}^{2}$ & 0.771 & 0.774 \\
\hline $\mathrm{R}^{2}$ & 0.789 & 0.778 \\
\hline
\end{tabular}

Source: Personal collection.

Note: Standard errors in brackets $* * * \mathrm{p}<0.01, * * \mathrm{p}<0.05, * \mathrm{p}<0.1$.

Narcissism, the main variable of interest in this study, was not statistically significant, implying no influence on the students' real performance. This result supports the second hypothesis according to which the students with higher levels of narcissistic personality traits do not tend to present real performance better than the average. Although there are theoretical reasons to argue that narcissism can make success more likely, the empirical results have consistently demonstrated that narcissistic individuals overestimate their performance. In other words, they tend to evaluate their performance as superior (a result also found in Model I), although real performance does not follow this same tendency (Gabriel et al., 1994; John \& Robins, 1994; Farwell \& Wohlwend-Lloyd, 1998).

Additionally, the model indicates the classification in the entrance exam, and his/her high school matter. Less ranked students when access the university entrance exam tend to be associated with better performance. This corroborates the idea that students' past performance influences their future performance, a fact already observed in previous studies (Kalbers \& Weinstein, 1999; Byrne \& Flood, 2008; Aldin et al., 2011; Ferreira et al., 2014; Baccaro, 2014). Although there are divergences regarding the proxies for past performance used in these studies, there are evidences that "[...] students who present satisfactory performance in the initial steps of their education will continue having satisfactory performance during the rest of their academic trajectory" (Ferreira et al., 2014, p. 2). This same aspect is articulated by the assimilation theory, as framed by David Ausubel (1968) the knowledge already accumulated by the student is the factor that has the greatest influence on future learning. 
The results instigate the discussion on whether the university and its teachers can improve the students' learning, and formulate strategies considering the students' prior knowledge. Also, special attention might be paid to students with deficient past performance, stimulating them to participate in tutoring sessions and study groups, etc., to help them improve their academic performance.

Students' experiences in high school also might be taken into consideration. Individuals from public high schools were better than their classmates from private school. This result is contrary to Queiroz (2003), Menezes Filho (2006), and Guimarães and Arraes (2008). The later found a better performance of students from private schools. However, Baccaro (2014) found similar results for the same University of São Paulo, for students enrolled in 12 majors (mathematics, gerontology, education, IT, nursing, philosophy, food engineering, nutrition, history, engineering, psychology, and business administration).

According to Baccaro (2014) some characteristics supporting better entrance exam results might have a negative impact on subsequent school performance, for instance, the high school one attended. The author pointed out that students from private high schools performed better in the entrance exam (Fuvest exam), but such effect is reversed for the performance during the undergraduate career. Professor Felipe Tarábola, vice-director of the School of Application of USP, in an interview published on the website "Tô no Rumo" ("I'm in Step") (Lopes, 2014), expressed the same perception: "Once the entrance exam barrier is overcome, what starts to count more are other variables. Many students from public schools who enter the university manage to take inventory of their difficulties regarding courses of study and dedicate their efforts to overcome their difficulties in the skills and workload demanded in the different courses."

A similar result was presented by Kassab (2006) for a sample with undergraduate students from the State University of Campinas (Unicamp), in São Paulo/Brazil. According the Dean, Mr. José Tadeu Jorge, interviewed by Jornal da Unicamp (Kassab, 2006), for the year 2005 the academic performance of the students enrolled in an internal preparatory program (Affirmative Action and Social Inclusion Program - PAAIS in Portuguese) were better than the remaining students for 31 of the 56 major programs. Under such program PAAIS, students from public schools accumulate points to be used at the entrance exam, then they tend to be better ranked at the exam. The performance was preserved in their freshman year at Unicamp. In other words, these students were ranked higher in Unicamp than they were in the entrance exam (Kassab, 2006).

\section{CONCLUSIONS}

Our results indicate the narcissistic personality traits tend to be associated with higher self-perceived performance, in which the narcissist person classifies his or her performance as superior. However, narcissism did not exert a significant influence on real performance. To the selected students, the real academic performance is associated with classification in the entrance exam and with the high school one attended (public or private). In this sense, individuals who were better classified in the entrance exam and those from public schools on average tend better perform on university courses.

The study aims to advance Brazilian accounting education literature including the aspects and effects of individuals personality traits, as a non-pathological feature which can harm the teaching-learning process. We intend to bring the topic to the local debate, and maybe incentive deans, course coordinators and senior faculties from Brazilian Universities to recognize narcissistic tendencies and look at alternatives to deal with associated uncomfortable situations which could emerge from such personality trait.

As limitations of the study was not considered the pathological narcissism, but just addressed a narcissism from a social perspective. Additionally, moderate effects between narcissism and the entrance exams classification were not considered. We finally suggest a wider debate regarding possible strategies to minimize the negative effects of heightened narcissism in the academic environment.

\section{REFERENCES}

Ackerman, R. A., Witt, E. A., Donnellan, M. B.; Trzesniewski, K. H.; Robins, R. W.; Kashy, D. A. (2011). What Does the Narcissistic Personality Inventory Really Measure? Assessment, 18(1), pp. 67-87.

Aldin, M. M., Nayebzadeh, S., \& Heirany, F. (2011). The Relationship between Background Variables and the Educational Performance (Case Study: Accounting MA Students). International Proceedings of Economics Development \& Research, 13. 
American Psychiatric Association. (2000). Diagnostic and statistical manual of mental disorders, 4 ed. Washington, DC: American Psychiatric Association.

Araújo, E. A. T., de Camargos, M. A., Camargos, M. C. S., \& Dias, A. T. (2014). Desempenho Acadêmico de Discentes do Curso de Ciências Contábeis: Uma análise dos seus fatores determinantes em uma IES Privada. Contabilidade Vista \& Revista, 24(1), 60-83.

Ausubel, D. P. (1968). Educational psychology: a cognitive view. New York, Holt, Rinehart, and Winston.

Avelino, B. C., \& Lima, G. A. S. F, (2017). Narcisismo e Desonestidade Acadêmica. Revista Universo Contábil, $13(3), 70$.

Avelino, B. C., Lima, G. A. S. F., Cunha, J. V. A., Colauto, R. D. (2017). The Influence of Narcissism in the Professional Environment: Aspects Related to Dishonesty. ASAA JOURNAL - Advances in Scientific and Applied Accounting, 10(3), 334-356.

Baccaro, T. A. (2014). A relação entre o desempenho no vestibular e o rendimento acadêmico no ensino superior: um estudo em uma universidade pública paulista. Tese (Doutorado em Administração de Organizações) Faculdade de Economia, Administração e Contabilidade de Ribeirão Preto, University of São Paulo.

Brown, A. D. (1997). Narcissism, identity, and legitimacy. Academy of Management Review, 22(3), 643-686.

Brown, R. P., Budzek, K. \& Tamborski, M. (2009). On the meaning and measure of narcissism. Personality and Social Psychology Bulletin, 35, pp. 951-964.

Brunell, A. B., Staats, S., Barden, J. \& Hupp, J. M. (2011). Narcissism and academic dishonesty: The exhibitionism dimension and the lack of guilt. Personality and Individual Differences, 50, pp. 323-328.

Bushman, B. J., \& Baumeister, R. F. (1998). Threatened egotism, narcissism, self-esteem, and direct and displaced aggression: Does self-love or self-hate lead to violence?. Journal of personality and social psychology, 75(1), 219.

Byrne, M., \& Flood, B. (2008). Examining the relationships among background variables and academic performance of first year accounting students at an Irish University. Journal of Accounting Education, 26(4), 202-212.

Caixeta, S. P. (2011). Sofrimento psíquico em estudantes universitários: um estudo exploratório. Dissertação (Mestrado em Psicologia) - Universidade Católica de Brasília, Brasília.

Campbell, W. K., Bonacci, A. M., Shelton, J., Exline, J. J., \& Bushman, B. J. (2004). Psychological entitlement: Interpersonal consequences and validation of a self-report measure. Journal of personality assessment, 83(1), $29-45$.

Campbell, W. K., Hoffman, B. J., Campbell, S. M., \& Marchisio, G. (2011). Narcissism in organizational contexts. Human Resource Management Review, 21(4), 268-284

Cornachione Jr., Cunha, J. V. A., De Luca, M. M. M., \& Ott, E. (2010). O bom é meu, o ruim é seu: perspectivas da teoria da atribuição sobre o desempenho acadêmico de alunos da graduação em Ciências Contábeis. Revista Contabilidade \& Finanças, 21(53), 1-23.

D’Souza, M. F. (2016). Manobras financeiras e o Dark Triad: o despertar do lado sombrio na gestão. Tese (Doutorado em Controladoria e Contabilidade) - Faculdade de Economia, Administração e Contabilidade da Universidade de São Paulo (FEA/USP), São Paulo.

Davis, M. S.; Brunell, A. B. (2012). Measuring Narcissism within Add Health: The Development and Validation of a New Scale. Journal of Research on Adolescence, 22(4), pp. 632-645.

Duckworth, A. L., \& Seligman, M. E. (2006). Self-discipline gives girls the edge: Gender in self-discipline, grades, and achievement test scores. Journal of educational psychology, 98(1), 198.

Dworkis, K. K. (2012). The Interactive Effects of Incentive Threshold and Narcissism on Managerial DecisionMaking. Dissertation, University of Southern California.

Farwell, L. \& Wohlwend-Lloyd, R. (1998). Narcissistic processes: Optimistic expectations, favorable selfevaluations, and self-enhancing attributions. Journal of Personality, 66, pp. 65-83.

Ferreira, M. A., Santos, C. K. S., Miranda, G. J. \& Leal, E. A. (2014). Desempenho Discente: O Passado Determina o Futuro? In: EnANPAD, XXXVIII, 2014. Rio de Janeiro-RJ. Anais... Curitiba: ANPAD, 2014. CD-ROM. 
Foster, J. D., Campbell, W. K., \& Twenge, J. M. (2003). Individual differences in narcissism: Inflated self-views across the lifespan and around the world. Journal of Research in Personality, 37(6), 469-486.

Gabriel, M. T.; Critelli, J. W.; Ee, J. S. (1994). Narcissistic illusions in self-evaluations of intelligence and attractiveness. Journal of Personality, 62, pp. 143-155.

Glad, B. (2002). Why tyrants go too far: Malignant narcissism and absolute power. Political Psychology, 23(1), 1-2

Godkin, L.; Allcorn, S. (2009). Institutional Narcissism, Arrogant Organization Disorder and Interruptions in Organizational Learning. The Learning Organization, 16(1), pp. 40-57.

Golmaryami, F. N.; Barry, C. T. (2010). The Associations of Self-Reported and Peer Reported Relational Aggression with Narcissism and Self-Esteem among Adolescents in a Residential Setting. J Clin Child Adolesc Psychol., 39(1), pp. 128-33.

Green, A. (1988). Narcissism de Vida, Narcisimo de Morte. São Paulo: Editora Escuta.

Guimarães, D. B., \& Arraes, R. A. (2010). Status Sócio-Econômico, Background Familiar, Formação Educacional e as Chances de Sucesso dos Candidatos ao Vestibular da UFC. Revista Contemporânea de Economia e Gestão, 8(2), 81-94.

Gungor, I. H.; Eksi, H.; Aricak, O. T. (2012). Value Preferences Predicting Narcissistic Personality Traits in Young Adults. Educational Sciences: Theory \& Practice, 12(2), pp. 1281-1290.

Hales, J.; Hobson, J. L.; Resutek, R. J. (2012). The Dark Side of Socially Mediated Rewards: How Narcissism and Social Status Affect Managerial Reporting. Working paper, Georgia Institute of Technology.

Hudson, E. J. (2012). Understanding and Exploring Narcissism: Impact on Students and College Campuses. CMC Senior Theses. Paper 381.

John, O. P., \& Robins, R. W. (1994). Accuracy and bias in self-perception: individual differences in selfenhancement and the role of narcissism. Journal of personality and social psychology, 66(1), 206.

Kalbers, L. P., \& Weinstein, G. P. (1999). Student performance in introductory accounting: A multi-sample, multimodel analysis. The Accounting Educators' Journal, 11.

Kassab, A. (2006). Alunos da escola pública têm melhor desempenho. Jornal da Unicamp. Available at: $<$ http:// www.unicamp.br/unicamp/unicamp_hoje/ju/junho2006/ju327pag03.html>. Consulted on: August 3, 2016.

Kernberg, O. (1975). Borderline conditions and pathological narcissism. New York: Jason Aronson.

Kets de Vries, M. F. (1994). The leadership mystique. The Academy of Management Executive, 8(3), 73-89

Kohut, H. (1977). The restoration of the self. New York: International Universities Press.

Langaro, F. N., \& Benetti, S. P. C. (2014). Subjetividade contemporânea: narcisismo e estados afetivos em um grupo de adultos jovens. Psicologia Clínica, 26(2).

Lasch, C. (1983). A cultura do narcissism: a vida americana numa era de esperanças em declínio. Rio de Janeiro: Imago.

Lopes, B. (2014). Estudantes de escola pública têm desempenho melhor na USP. Tô no Rumo. Available at: $<$ http://www.tonorumo.org.br/2014/10/estudantes-de-escola-publica-tem-desempenho-melhor-na-usp/>. Consulted on: August 3, 2016.

Lopes, S. S., Cardoso, P. R., Reina, D., \& Reina, D. R. M. (2016). Dark Triad: Análise Do Perfil De Personalidade Em Estudantes Da Área Contábil. In: Congresso UnB de Contabilidade e Governança, 2, 2016. Brasília, Anais... Brasília: UnB, 2016.

Maccoby, M. (2003), The Productive Narcissist: The Promise and Peril of Visionary Leadership. New York: Broadway Books.

Magalhães, F. A. C. \& Andrade, J. X. (2006). Exame vestibular, characteristics demográficas e desempenho na universidade: em busca de fatores preditivos. In: Congresso USP de Controladoria e Contabilidade, 6., 2006, São Paulo/SP. Anais... São Paulo: FEA-USP, 2006.

Mazlish, B. (1982). American Narcissism. The Psychohistory Review, 10(3-4), pp. 185-202. 
Menezes Filho, N. A. (2006). Os determinantes do desempenho escolar do Brasil. São Paulo: Instituto Futuro Brasil, IBMEC, FEA/USP, 2006.

Menon, M. K. \& Sharland, A. (2011). Narcissism, Exploitative Attitudes, and Academic Dishonesty: An Exploratory Investigation of Reality Versus Myth. Journal of Education for Business, 86, pp. 50-55.

Miller, J. D., \& Campbell, W. K. (2008). Comparing Clinical and Social-Personality Conceptualizations of Narcissism. Journal of Personality, 76(3), 449-476.

Miller, J. D., Campbell, W. K., Young, D. L., Lakey, C. E., Reidy, D. E., Zeichner, A., \& Goodie, A. S. (2009). Examining the relations among narcissism, impulsivity, and self-defeating behaviors. Journal of Personality, 77(3), 761-794.

Millon, T. (1981). Disorders of Personality. New York: Wiley.

Pauletti, R. E.; Menon, M.; Menon, M.; Tobin, D. D.; Perry, D. G. (2012). Narcissism and Adjustment in Preadolescence. Child Development, 83(3), pp. 831-837.

Penney, S. R.; Moretti, M. M.; Silva, K. S. (2008). Structural Validity of the MACI Psychopathy and Narcissism Scales: Evidence of Multidimensionality and Implications for Use in Research and Screening. J Clin Child Adolesc Psychol., 37(2), pp. 422-433.

Queiroz, D. M. (2003). Desigualdade no Ensino Superior: cor, status e desempenho. In: $26^{\mathrm{a}}$ Reunião Anual da Associação Nacional de Pós-Graduação e Pesquisa em Educação: Novo Governo. Novas Políticas, 5.

Raskin, R. N. \& Hall, C. S. (1979). A narcissistic personality inventory. Psychological Reports, 45(2), pp. 590.

Raskin, R., \& Terry, H. (1988). A principal-components analysis of the Narcissistic Personality Inventory and further evidence of its construct validity. Journal of personality and social psychology, 54(5), 890.

Rhodewalt, F., \& Morf, C. C. (1995). Self and interpersonal correlates of the Narcissistic Personality Inventory: A review and new findings. Journal of Research in Personality, 29(1), 1-23.

Robins, R. W., \& Beer, J. S. (2001). Positive illusions about the self: Short-term benefits and long-term costs. Journal of Personality and Social Psychology, 80(2), pp. 340- 352.

Rojas, A. (2007). La autoestima: nuestra fuerza secreta. Madrid: Espasa Calpe.

Romanek, J. L. (2009). The Relative Influence of Sensation Seeking and Normal Narcissism on Academic Cheating in Emerging Adults. Ph.D. Dissertation, Northcentral University.

Severiano, M. F. V. (1999). As Subjetividades Contemporâneas sob o Signo do Consumo - os Ideais Narcísicos na Publicidade da TV: Produção e Consumo. Tese (Doutorado em Educação) - Faculdade de Educação da Universidade Estadual de Campinas, São Paulo.

Taylor, J. (2005). Substance use disorders and cluster B personality disorders: Physiological, cognitive, and environmental correlates in a college sample. The American journal of drug and alcohol abuse, 31(3), pp. 515-535.

Trechera, J. L., Torre, G. M. V. \& Morales, E. F. (2008). Estudio Empírico del Trastorno Narcisista de da Personalidad (TNP). Acta Colombiana de Psicología, 11(2), pp. 25-36.

Trzesniewski, K. H., Donnellan, M. B., \& Robins, R. W. (2008). Do today's young people really think they are so extraordinary? An examination of secular trends in narcissism and self-enhancement. Psychological Science, 19(2), 181-188.

Twenge, J. M., \& Campbell, W. K. (2003). “Isn't it fun to get the respect that we're going to deserve?" Narcissism, social rejection, and aggression. Personality and Social Psychology Bulletin, 29(2), 261-272.

University of São Paulo - USP (2016). Available at: <http://www5.usp.br/institucional/a-usp/>. Consulted on: January 19, 2016.

Valadez, J.; Clignet, R.(1987). On the ambiguities of a Sociological Analysis of the Culture of Narcissism. The Sociological Quarterly, 28(4), pp. 455-472.

Wallace, H. M. \& Baumeister, R. F. (2002). The Performance of Narcissists Rises and Falls with Perceived Opportunity for Glory. Journal of Personality and Social Psychology, 82(5), p. 819-834. 
Watson, J. M. (2012). Educating the Disagreeable Extravert: Narcissism, the Big Five Personality Traits, and Achievement Goal Orientation. International Journal of Teaching and Learning in Higher Education, 24(1), pp. 76-88.

Weikel, K. A., Avara, R. M., Hanson, C. A., \& Kater, H. (2010). College adjustment difficulties and the overt and covert forms of narcissism. Journal of College Counseling, 13(2), 100-110.

Westerman, J. W.; Bergman, J. Z.; Bergman, S. M.; Daly, J. P. (2012). Are universities creating millennial narcissistic employees? An empirical examination of narcissism in business students and its implications. Journal of Management Education, 36(1), pp. 5-32.

Young, S. M., \& Pinsky, D. (2006). Narcissism and celebrity. Journal of Research in Personality, 40(5), $463-471$.

APPENDIX: Questionnaire

Part I: Respondent Profile (Avelino, Lima, Cunha \& Colauto, 2017).

I.1) Course:

1.2) USP Number:

I.3) Age:

I.4) Gender:

( ) Male

( ) Female

I.5) Month/year of joining the course:

I.6) Expected month/year of graduation:

I.7) Marital Status: ( ) Single

( ) Married / In a civil union

( ) Divorced

( ) Widow(er)

1.8) What is the highest level of education attained by your mother?

( ) Middle school

( ) High school

( ) Graduate degree

1.9) What is the highest level of education attained by your father?

( ) Middle school

( ) High school

( ) Graduate degree

I.10) Type of institution where you spent most high school years:

( ) Public high schools

( ) Private high schools

I.11) Besides studying, are you engaged in any unpaid activity that takes up a significant part of your day (e.g. scientific initiation project with a grant, helping your parents in the family business)?

( ) Yes

( ) No 
I.12) Are you engaged in any paid activity (e.g. scientific initiation project with a grant, internship, job)?

( ) Yes

( ) No

\section{Part II: Narcissistic Personality Inventory - NPI (Raskin \& Terry, 1988)}

\section{Instructions:}

In each one of the following pairs of attitudes, choose the statement from column A or B that best suits you. Indicate your answer by marking one item for each number. There are no right or wrong answers. Please, answer based on your beliefs and not in the way you think you should in order to present a good image to the researcher. Mark only one answer for each pair of attitudes and, PLEASE, DO NOT SKIP ANY OF THE ITEMS.

\begin{tabular}{|c|c|c|}
\hline & $\mathbf{A}$ & $\mathbf{B}$ \\
\hline 1. & ( ) - I have a natural talent for influencing people. & ( ) - I am not good at influencing people. \\
\hline 2. & ( ) - Modesty doesn't become me. & ( ) - I am essentially a modest person. \\
\hline 3. & ( ) - I would do almost anything on a dare. & ( ) - I tend to be a fairly cautious person. \\
\hline 4. & $\begin{array}{l}\text { ( ) - When people compliment me I sometimes get } \\
\text { embarrassed. }\end{array}$ & $\begin{array}{l}\text { ( ) - I know that I am good because everybody keeps } \\
\text { telling me so. }\end{array}$ \\
\hline 5. & $\begin{array}{l}\text { ( ) - The thought of ruling the world frightens the hell } \\
\text { out of me. }\end{array}$ & ( ) - If I ruled the world it would be a better place. \\
\hline 6. & ( ) - I can usually talk my way out of anything. & ( ) - I try to accept the consequences of my behavior. \\
\hline 7. & ( ) - I prefer to blend in with the crowd. & ( ) - I like to be the center of attention. \\
\hline 8. & ( ) - I will be a success. & ( ) - I am not too concerned about success. \\
\hline 9. & ( ) - I am no better or worse than most people. & ( ) - I think I am a special person. \\
\hline 10. & ( ) - I am not sure if I would make a good leader. & ( ) - I see myself as a good leader. \\
\hline 11. & () - I am assertive. & ( ) - I wish I were more assertive. \\
\hline 12. & ( ) - I like to have authority over other people. & ( ) - I don't mind following orders. \\
\hline 13. & ( ) - I find it easy to manipulate people. & $\begin{array}{l}\text { ( ) - I don't like it when I find myself manipulating } \\
\text { people. }\end{array}$ \\
\hline 14. & ( ) - I insist on getting the respect that is due me. & ( ) - I usually get the respect that I deserve. \\
\hline 15. & ( ) - I don't particularly like to show off my body. & ( ) - I like to show off my body. \\
\hline 16. & ( ) - I can read people like a book. & ( ) - People are sometimes hard to understand. \\
\hline 17. & $\begin{array}{l}\text { ()-If I feel competent I am willing to take responsibility } \\
\text { for making decisions. }\end{array}$ & ( ) - I like to take responsibility for making decisions. \\
\hline 18. & ( ) - I just want to be reasonably happy. & $\begin{array}{l}\text { ( ) - I want to amount to something in the eyes of } \\
\text { the world. }\end{array}$ \\
\hline 19. & ( ) - My body is nothing special. & ( ) - I like to look at my body. \\
\hline 20. & ( ) - I try not to be a show off. & ( ) - I will usually show off if I get the chance. \\
\hline 21. & ( ) - I always know what I am doing. & ( ) - Sometimes I am not sure of what I am doing. \\
\hline 22. & ( ) - I sometimes depend on people to get things done. & () - I rarely depend on anyone else to get things done. \\
\hline 23. & ( )-Sometimes I tell good stories. & ( ) - Everybody likes to hear my stories. \\
\hline 24. & ( ) - I expect a great deal from other people. & ( ) - I like to do things for other people. \\
\hline 25. & ( ) - I will never be satisfied until I get all that I deserve. & ( ) - I take my satisfactions as they come. \\
\hline 26. & ( )-Compliments embarrass me. & ( ) - I like to be complimented. \\
\hline 27. & ( ) - I have a strong desire for power. & ( ) - Power for its own sake doesn't interest me. \\
\hline 28. & ( ) - I don't care about new fads and fashions. & ( ) - I like to start new fads and fashions. \\
\hline & ( ) - I like to look at myself in the mirror. & $\begin{array}{l}\text { ( ) - I am not particularly interested in looking at } \\
\text { myself in the mirror. }\end{array}$ \\
\hline & ( ) - I really like to be the center of attention. & $\begin{array}{l}\text { ( ) - It makes me uncomfortable to be the center of } \\
\text { attention. }\end{array}$ \\
\hline
\end{tabular}




\begin{tabular}{|c|c|c|}
\hline 31. & ( ) - I can live my life in any way I want to. & $\begin{array}{l}\text { ( ) - People can't always live their lives in terms of } \\
\text { what they want. }\end{array}$ \\
\hline 32. & ( ) - Being an authority doesn't mean that much to me. & ( ) - People always seem to recognize my authority. \\
\hline 33. & ( ) - I would prefer to be a leader. & $\begin{array}{l}\text { ( ) - It makes little difference to me whether I am a } \\
\text { leader or not. }\end{array}$ \\
\hline 34. & ( ) - I am going to be a great person. & ( ) - I hope I am going to be successful. \\
\hline 35 . & ( ) - People sometimes believe what I tell them. & $\begin{array}{l}\text { ( ) - I can make anybody believe anything I want } \\
\text { them to. }\end{array}$ \\
\hline 36. & ( ) - I am a born leader. & $\begin{array}{l}\text { ( ) - Leadership is a quality that takes a long time to } \\
\text { develop. }\end{array}$ \\
\hline 37. & $\begin{array}{l}\text { ( ) - I wish somebody would someday write my } \\
\text { biography. }\end{array}$ & $\begin{array}{l}\text { ( ) - I don't like people to pry into my life for any } \\
\text { reason. }\end{array}$ \\
\hline 38. & $\begin{array}{l}\text { ( ) - I get upset when people don't notice how I look } \\
\text { when I go out in public. }\end{array}$ & $\begin{array}{l}\text { ( ) - I don't mind blending into the crowd when I go } \\
\text { out in public. }\end{array}$ \\
\hline 39. & ( ) - I am more capable than other people. & ( ) - There is a lot that I can learn from other people. \\
\hline 40. & ( ) - I am much like everybody else. & ( ) - I am an extraordinary person. \\
\hline
\end{tabular}

\section{Part III: Academic Performance}

III.1) How do you evaluate your performance over the course of the previous semesters (or over the course of the current semester, in the case of those starting in 2016), in comparison with your peers?

( ) Superior performance (above average - highest 50\%)

( ) Inferior performance (below average - lowest 50\%) 